\title{
Effects of oxidised oil and vitamin $E$ on performance and some blood traits of heat-stressed male broilers
}

\author{
H. Bayraktar ${ }^{1 \#}$, Ö. Altan ${ }^{1}$, Z. Açıkgöz ${ }^{1}$, Ş.H. Baysal ${ }^{2}$ \& Ç. Şeremet ${ }^{1}$ \\ ${ }^{1}$ Faculty of Agriculture, Department of Animal Science, Ege University, Bornova, Izmir, Turkey \\ ${ }^{2}$ Faculty of Sciences, Department of Biochemistry, Ege University, Bornova, Izmir, Turkey
}

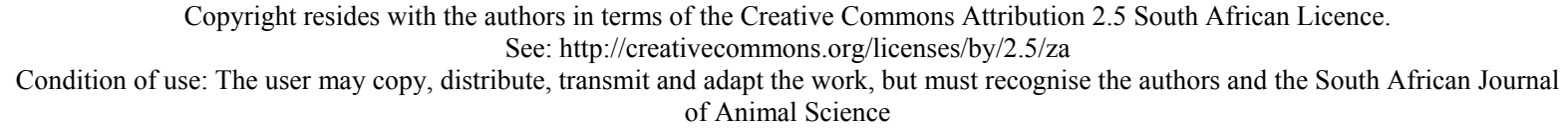

Copyright resides with the authors in terms of the Creative Commons Attribution 2.5 South African Licence. See: http://creativecommons.org/licenses/by/2.5/za

Condition of use: The user may copy, distribute, transmit and adapt the work, but must recognise the authors and the South African Journal of Animal Science

\begin{abstract}
The present study was conducted so that the possible effects of thermally-oxidised dietary oil and vitamin E supplementation could be determined on the performance, lipid peroxidation, antioxidant defence system and some blood and meat quality traits of broilers. Broilers were fed grower diets containing fresh or oxidised oil, supplemented with and without vitamin E $(200 \mathrm{mg} / \mathrm{kg})$ from four to six weeks of age. Neither oxidised dietary oil nor vitamin $\mathrm{E}$ supplementation had any adverse effect on weight gain, feed consumption or feed conversion ratio. However, the broilers that received oxidised oil had lower levels of plasma cholesterol and triglyceride compared to the control. The glucose level was neither influenced by oxidised oil nor by vitamin E supplementation. The plasma malondialdehyde level increased slightly in broilers fed oxidised oil, indicating increased lipid peroxidation. Higher glutathione peroxidise $\left(\mathrm{GSH}-\mathrm{P}_{\mathrm{x}}\right)$ activity observed in the broilers fed oxidised oil suggests greater oxidative stress. Vitamin E supplementation partly depressed GSH- $\mathrm{P}_{\mathrm{x}}$ activity in broilers fed oxidised oil. This depression in enzyme activity might be the result of homeostatic compensation. The uric acid concentration was not affected by oxidised oil and vitamin $\mathrm{E}$ supplementation. Feeding oxidised oil did not cause a marked discolouration in breast meat. Vitamin $\mathrm{E}$ supplementation had some beneficial effects on colour measurements.
\end{abstract}

Keywords: Lipid peroxidation, oxidative stress, poultry, performance, meat colour

${ }^{\#}$ Corresponding author: ozer.hakan.bayraktar@ege.edu.tr

\section{Introduction}

Vegetable oils, rich in polyunsaturated fatty acids (PUFAs), are highly digestible in chickens and are used in relatively large quantities in broiler diets to increase growth rate (Engberg et al., 1996). However, oils are susceptible to oxidation during storage and after addition to the diet, especially under the promoting effects of oxygen, high temperatures or metallic catalysts. Lipid oxidation is a serious problem to both the food industry and the consumer, because it shortens the shelf life of meat and meat products, and increases the development of rancid odours and flavours. In addition, free radicals formed during oxidation may be a potential health risk to consumers (Jakobsen, 1999).

Furthermore, the usage of oxidised oil in diets can lead to growth depression in poultry (Cabel et al., 1988; Lin et al., 1989; Sheehy et al., 1994; Dibner et al., 1996; Engberg et al., 1996; Jankowski et al., 2000) and in other animal species (Keller et al., 2004). It has been suggested that growth depression might be due to a reduction in feed intake as a result of reduced palatability and off flavour of rancid feed, or a decrease in digestibility of the oxidised oil (Wideman, 1986; Zdunczyk et al., 2000; 2002).

The ingestion of oxidised oils also reduces tocopherol levels of tissues and plasma (Sheehy, 1993; Fei, 1995; Eder, 1999a; Jankowski et al., 2000) and increases the amount of thiobarbituric acid-reactive substances (TBARS), suggesting an elevation in lipid peroxidation and cellular fragility (Asghar, 1989; Sheehy et al., 1993; 1994; Fei, 1995; Enberg et al., 1996; Eder \& Kirchgessner, 1999; Juskiewicz et al., 2000). Similarly, Zdunczyk et al. (2000) and Keller et al. (2004) reported that oxidised dietary oils lead to a reduced antioxidant status of erythrocytes and make them more susceptible to haemolysis. It is also suggested that these detrimental effects of oxidised dietary oils can be alleviated by vitamin E supplementation (Jakobsen et al., 1993; Sheehy et al., 1993; Dibner et al., 1996; Keller et al., 2004). 
Increasing the fat content of diets helps birds to cope with heat stress and can overcome growth depression in broilers (Gous \& Morris, 2005). However, special care should be taken to prevent fat oxidation at high ambient temperatures. Jankowski et al. (2001) reported that short and long-term feeding of diets containing oxidised oils decreased the final body weight of turkeys kept at high environmental temperatures. Furthermore, raising the fat level in diets by using vegetable oils, can promote oxidation problems in meat and meat products.

Heat stress stimulates the release of corticosterone from the adrenal gland, initiates lipid peroxidation in the cell membrane and leads to the generation of free radicals (Etches et al., 1995). These free radicals can damage cell membranes by inducing lipid peroxidation of PUFAs in the cell membrane (Halliwell et al., 1992; Yu, 1994; Etches et al., 1995; Altan et al., 2000; 2003). However, the peroxidation induced by heat stress might disappear upon the stimulation of the antioxidation ability (Lin et al. 2000). Puthpongsiriporn et al. (2001) also reported that lipid peroxidation in yolk and plasma, induced by heat stress, can be ameliorated by vitamin E supplementation. Therefore, the requirements of vitamin $\mathrm{E}$ for stabilization of cell membrane oxidation, are higher during heat stress (Kirunda et al., 2001).

Generally, feed producers do not use oil with a high peroxide value in animal diets. However, feedstuffs stored in silos or broiler diets stocked on farms, especially during high summer temperatures, can easily undergo thermal oxidation, resulting in potentially toxic lipid peroxidation products. There are a few studies in which the effects of oxidised oil and vitamin E supplementation have been evaluated on the performance of broilers exposed to heat stress. Therefore, lipid peroxidation induced by heat stress and oxidised dietary oils in broilers must be taken into consideration.

The aim of the present study was to determine the possible effects of oxidised dietary oils on lipid peroxidation, some biochemical and production parameters of broilers reared under a high ambient temperature, and to determine whether vitamin E supplementation is able to alleviate the possible adverse effects of oxidised oil on lipid peroxidation. Colour measurements of breast muscle were also evaluated to determine whether oxidised dietary oil resulted in colour deterioration.

\section{Materials and Methods}

Three hundred and eighty-four day-old male chicks (Ross 308) were obtained from a commercial hatchery and randomly assigned to three dietary treatments with four replications ( 32 chicks per pen). The birds were maintained in an open-sided broiler house and received feed and water ad libitum. A lighting programme of $1 \mathrm{~h}$ dark : $23 \mathrm{~h}$ light was provided during the experimental period. The average daily temperature and relative humidity inside the house ranged from 30 to $35{ }^{\circ} \mathrm{C}$ and 50 to $70 \%$, respectively. Individual body weights and feed intake for each pen were measured at four and six weeks of age, and mortality was recorded daily. The feed conversion ratio (FCR) was adjusted for mortality.

All birds were fed a commercial starter diet $(235 \mathrm{~g}$ crude protein $/ \mathrm{kg}$ and $12.68 \mathrm{MJ}$ metabolizable energy $/ \mathrm{kg}$ ) for the first three weeks. From four to six weeks of age the experimental birds received one of three grower diets, all containing 13.3 MJ metabolizable energy $/ \mathrm{kg}$ and $219.1 \mathrm{~g}$ crude protein $/ \mathrm{kg}$ (Table 1). The basal diet (control), prepared with fresh sunflower oil, was supplemented with a vitamin premix containing $75 \mathrm{mg} \alpha$-tocopherol acetate $/ \mathrm{kg}$. The second group received the basal diet containing oxidised sunflower oil (100 meq $\mathrm{O}_{2} / \mathrm{kg}$ oil). The third group was fed the same diet as the second, but was supplemented with $\alpha$-tocopherol acetate at a level of $200 \mathrm{mg} / \mathrm{kg}$. The chemical composition of the diets was determined according to Verband Deutscher Landwirtschaftlicher Untersuchungs und Forschungsanstalten, VDLUFA (Naumann \& Bassler, 1993). The metabolizable energy content of the diets was calculated from the chemical composition (TS, 1991). Sunflower oil was saturated with oxygen and intensively aerated during a heating process at $70-80^{\circ} \mathrm{C}$ until the peroxide value reached $100 \mathrm{meq} \mathrm{O}_{2} / \mathrm{kg}$ oil (Zduńczyk et al., 2000). The peroxide analysis was performed in accordance with the procedures recommended by TS (2006).

At the end of the study, 12 broilers from each group were slaughtered and their $p$. majors were immediately removed from the right side of the carcasses, wrapped in film and stored at $4{ }^{\circ} \mathrm{C}$ for $24 \mathrm{~h}$ for $\mathrm{pH}$ and colour measurements. The $\mathrm{pH}$ values were measured in each breast muscle at three different locations, using a digital $\mathrm{pH}$ meter (Hanna Instruments H1 8314). Objective colour was measured at the surface of skinless breast samples using a reflectance spectrophotometer (Minolta CM 508d). Each colour parameter ( $\mathrm{L}^{*}=$ brightness, $\mathrm{a}^{*}=$ redness and $\mathrm{b}^{*}=$ yellowness) was taken at three different locations across the $p$. major (CIE, 1986). 
A sample of $5 \mathrm{~mL}$ of blood was obtained from the wing vein of 13 birds per treatment and kept in an ice bath until the laboratory analysis could be performed. Blood samples were divided into two. The one subsample was used immediately after collection for antioxidant enzyme analysis. The second subsample was centrifuged at $4000 \mathrm{rpm}$ for $10 \mathrm{~min}$ at $4{ }^{\circ} \mathrm{C}$ to separate plasma and stored at $-70{ }^{\circ} \mathrm{C}$, for later cholesterol, triglyceride and glucose analysis. Randox cholesterol, triglycerides and glucose Liquid Enzymatic Colorimetric Method kits (Randox Laboratories, Ardmore, Crumlin, UK) were used which are based on the CHOD-PAP, Glycerol-Phosphate Oxidase and GOD-PAP methods, respectively. Glutathione peroxidise $\left(\mathrm{GSH}-\mathrm{P}_{\mathrm{x}}\right)$ activity was determined using a commercially available enzyme kit (Ransel, RANDOX/RS-504) supplied by Randox Laboratories, Ardmore, Crumlin, UK. The Randox Uric Acid Enzymatic Colorimetric method kit was used for uric acid analysis. Uric acid is converted by uricase to allantoin and hydrogen

Table 1 The ingredient and chemical composition of starter and grower diets

\begin{tabular}{lrr}
\hline Ingredients $(\mathrm{g} / \mathrm{kg})$ & $\begin{array}{c}\text { Starter diet } \\
(0 \text { to } 3 \text { weeks })\end{array}$ & $\begin{array}{c}\text { Grower diet } \\
\text { (4 to 6 weeks) }\end{array}$ \\
\hline Maize & 504 & 494 \\
Sunflower meal & 56 & 64 \\
Soybean meal & 209 & 211 \\
Full-fat soybean & 120 & 129 \\
Maize gluten meal & 40 & 4.5 \\
Dicalcium phosphate & 16.7 & 13.4 \\
Limestone & 9.8 & 10.5 \\
Sunflower oil & 31.5 & 60 \\
Vitamin mixture & 2 & 2 \\
Mineral mixture & 1 & 1 \\
Choline chloride & 1 & 0.65 \\
L-Lysine & 0.65 & 3.5 \\
DL-Methionine & 3.9 & 1.7 \\
L-Threonine & 1.45 & 0.25 \\
Salt & - & 4.0 \\
Coccidiostat ${ }^{3}$ & 4.0 & 0.5 \\
Chemical composition $(\mathrm{g} / \mathrm{kg})$ & 0.5 & \\
Dry matter & & 928 \\
Crude protein & 918 & 219 \\
Crude fibre & 235 & 35.0 \\
Crude ash & 33.7 & 51.6 \\
Ether extract & 52.1 & 113 \\
Total calcium & 74.3 & 10.7 \\
Total phosphorus & 10.7 & 7.1 \\
ME (MJ/kg) & 7.1 & \\
\hline
\end{tabular}

\footnotetext{
${ }^{1}$ Provides per kg of diet: retinol acetate, $4.3 \mathrm{mg}$; cholecalciferol, $0.125 \mathrm{mg}$; tocopheryl, $75 \mathrm{mg}$; menadione, $4 \mathrm{mg}$; thiamine, $3 \mathrm{mg}$; riboflavin, $9 \mathrm{mg}$; niacin, $70 \mathrm{mg}$; calcium D-pantothenate, $18 \mathrm{mg}$; pyridoxine, $5 \mathrm{mg}$; cyanocobalamin, $0.02 \mathrm{mg}$; folic acid, $2 \mathrm{mg}$; D-biotin $0.1 \mathrm{mg}$; ronozyme P $750 \mathrm{FYT}$.

${ }^{2}$ Provides per kg of diet: manganese, $100 \mathrm{mg}$; iron, $60 \mathrm{mg}$; zinc, $60 \mathrm{mg}$; copper, $5 \mathrm{mg}$; cobalt, $0.2 \mathrm{mg}$; iodine, $1 \mathrm{mg}$; selenium, $0.15 \mathrm{mg}$.

${ }^{3}$ Provides per kg of diet: $66 \mathrm{mg} / \mathrm{kg}$ salinomycin sodium (Bio-Cox). Not supplemented to grower diet for the last five days of the experiment.
} 
peroxide, which is under the catalytic influence of peroxidase, oxidizes 3.5-Dichloro-2hydroxybenzenesulfonic acid and 4-aminophenazone to form a red-violet quinoneimine compound. Lipid peroxidation was measured using the TBA method (Satoh, 1978; Yagi, 1984). This method evaluates the oxidative stress assayed for malondialdehyde (MDA), the last product of lipid breakdown caused by oxidative stress.

Data was subjected to one-way ANOVA using the General Linear Model Procedure of SAS (1985). Means were compared using the Duncan test $(\alpha=0.05)$.

\section{Results and Discussion}

The effects of oxidised oil and vitamin E supplementation on broiler performance are shown in Table 2. Oxidised dietary oil and vitamin E supplementation did not affect body weight gain and feed intake during the four to six week experimental periods. These results agree with other studies which reported that body weight and feed intake were not adversely affected by oxidised oil in rats (Zdunczyk et al, 2000.; Eder et al., 2002; Keller et al., 2004) and in miniature pigs (Eder, 1999b). There were no differences in FCR of the treatment groups, which is in accordance with the results reported for broilers by Lin et al. (1989) and Engberg et al. (1996).

The findings showed that body weight and FCR were not adversely affected by oxidised oil and implied that oxidised oil did not alter palatability, odour or digestibility of the diet. In fact, it is reported that neither protein nor fat digestibility was affected by mildly oxidised oil (Zdunczyk et al., 2000). In contrast, there are some studies that report depressed growth and impaired health in birds fed oxidised oil (Lin et al., 1989; Jacobsen et al., 1993; Sheehy et al., 1993; Engberg et al., 1996; Jankowski et al., 2000; Zdunczyk et al., 2002; Eder et al., 2003). In these studies, the detrimental effects of oxidised oil may be due to the administration of oils with high peroxide values or higher secondary lipid peroxidation products which have toxic effects. In the present study the peroxide value of the grower diet was $6.0 \mathrm{meq} / \mathrm{kg}$ and was lower than in most other studies. Interestingly, an increased cell proliferation in the gut and liver of birds fed oxidised oil occurred, suggesting that it may be related to a reduced FCR because of an increase in the maintenance requirement of these tissues (Fei, 1995; Dibner et al., 1996). The supplementation of oxidised oil, with or without vitamin E, to grower diets did not affect the levels of glucose and total cholesterol in plasma. However, the triglyceride level in plasma was strongly influenced by the oxidised oil treatment. The birds fed oxidised oil had a significantly lower triglyceride level in their plasma than the control group. The depression in the triglyceride level caused by oxidised oil was less pronounced in the group supplemented with vitamin $\mathrm{E}$ (Table 3). The effects of oxidised oil on cholesterol and triglyceride concentrations are largely speculative. While some researchers obtained no significant effects in rats (Eder, 1999a) or birds (Juskiewicz, 2000), others reported that oxidised dietary oil reduces cholesterol and triglyceride concentrations (Eder \& Kirchgessner, 1999; Eder, 1999b; Eder et al., 2003). However, Narasimhamurthy \& Raina (1999) observed higher cholesterol and lower triglyceride concentrations in the plasma of rats fed heated/fried oils compared to the fresh group. The reduction in cholesterol concentrations has been explained by elevated faecal excretion of cholesterol, impaired liver cholesterol uptake (Hocgraf et al., 2000) and increased plasma thyroxin levels (Eder, 1999a). However, the oxidised oil-induced decline in triglyceride

Table 2 The effects of moderately-oxidised oil and vitamin E supplementation to grower diet on performance

\begin{tabular}{lccc}
\hline Treatment groups & $\begin{array}{c}\text { Body weight gain* }(\mathrm{g}) \\
\text { 4 to 6 weeks }\end{array}$ & $\begin{array}{c}\text { Feed intake* }(\mathrm{g}) \\
\text { 4 to 6 weeks }\end{array}$ & $\begin{array}{c}\text { FCR* }(\mathrm{g} / \mathrm{g}) \\
\text { 4 to 6 weeks }\end{array}$ \\
\hline Control & $1517 \pm 23.9$ & $3240 \pm 27.5$ & $2.21 \pm 0.06$ \\
Oxidised oil & $1520 \pm 30.6$ & $3274 \pm 22.2$ & $2.17 \pm 0.04$ \\
Oxidised oil + vitamin E & $1516 \pm 27.1$ & $3327 \pm 79.2$ & $2.25 \pm 0.05$ \\
\hline Source of variation & & Probabilities $(P$ value $)$ & 0.570 \\
\hline Group & 0.995 & 0.494 & \\
\hline
\end{tabular}

${ }^{*} \mathrm{LS}$ Mean \pm SEM; FCR - feed conversion ratio (g feed/g gain). 
concentrations might be due to a reduced de novo synthesis of fatty acids (Eder \& Kirchgessner, 1998; 1999; Eder, 1999b). Fei (1995) suggested that birds fed oxidised oil had a higher glucose uptake capacity primarily due to an increase in the energy-dependent uptake. However, in the present study the plasma glucose level of the oxidised oil group did not differ from that of the fresh oil group.

There was a large individual variation in response to the oxidised oil treatment, ranging from $0.08 \mu \mathrm{M}$ to $1.17 \mu \mathrm{M}$, but no statistically significant differences were obtained among treatment groups for MDA concentrations (Table 3). Nevertheless, the birds fed the oxidised oil diet showed a tendency towards a higher MDA concentration in erythrocytes compared to the control group, suggesting an increase in lipid peroxidation. In other words, the vitamin $\mathrm{E}$ level of the basal diet might be insufficient to ensure optimum protection against the damaging effect of oxidised oil. These results seem to agree with many previous reports in which higher TBARS levels were obtained in birds fed oxidised oil (Sheehy et al., 1993; 1994; Engberg et al., 1996). Similar findings have also been reported in rats (Eder \& Kirchgessner, 1999; Juskiewicz et al., 2000; Eder et al., 2003; Tabatabaei, 2008). However, Eder (1999a) suggested that the susceptibility of plasma lipids to lipid peroxidation was not significantly affected by feeding oxidised oil to miniature pigs.

Vitamin E, a major chain-breaking antioxidant of membranes, can scavenge the hydroxyl, alkoxyl, peroxyl and superoxide anion radicals and increase membrane stability (Surai, 2003). Dietary vitamin E supplementation has been shown to protect cells from oxidative stress mediated by oxidised oil and to improve the stability of meat (Lin et al., 1989; Wang et al., 1997; Asghar et al., 1999). Supporting these results was the negative correlation between the dietary vitamin $\mathrm{E}$ and hepatic TBARS levels obtained by Mercier et al. (1998) and Guo et al. (2001).

In this study, although the effect of vitamin E supplementation was not statistically significant, the lower MDA levels of the vitamin E supplemented group $(0.49 \pm 0.09 \mu \mathrm{M})$ compared with the oxidised oil group $(0.60 \pm 0.05 \mu \mathrm{M})$ might be a sign of the beneficial effect of vitamin $E$ in alleviating oxidative damage induced by the oxidised oil. In agreement with our findings, Eder \& Kirchgessner (1998) reported that with a low vitamin E supply, the susceptibility of low-density lipoprotein (LDL) to lipid peroxidation was slightly increased by feeding oxidised oil. In contrast, with a high vitamin E supply, there was no adverse effect by using oxidised dietary oil on the susceptibility of LDL to lipid peroxidation. Higher levels of vitamin E may be sufficient to scavenge free radicals or increase fatty acid saturation and decrease instauration, thus making lipids more resistant to lipid peroxidation (Barja et al., 1996; Iqbal et al., 2002). The activity of GSH-Px was significantly different, with the oxidised oil group having the highest value, the vitamin E supplemented group the lowest value and fresh oil group having an intermediate GSH-Px activity (Table 3).

Table 3 The effects of moderately-oxidised oil and vitamin E supplementation in the grower diet, on the plasma lipid and glucose levels, lipid peroxidation and antioxidant defence system

\begin{tabular}{|c|c|c|c|c|c|c|}
\hline $\begin{array}{c}\text { Treatment } \\
\text { groups }\end{array}$ & $\begin{array}{c}\text { Triglyceride }^{*} \\
(\mathrm{mmol} / \mathrm{L})\end{array}$ & $\begin{array}{c}\text { Cholesterol }^{*} \\
(\mathrm{mmol} / \mathrm{L})\end{array}$ & $\begin{array}{c}\text { Glucose }^{*} \\
(\mathrm{mmol} / \mathrm{L})\end{array}$ & $\begin{array}{l}\text { MDA }^{*} \\
(\mu \mathrm{M})\end{array}$ & $\begin{array}{c}\text { GSH-Px }^{*} \\
(\mathrm{U} / \mathrm{L})\end{array}$ & $\begin{array}{c}\text { Uric acid }^{*} \\
(\mu \mathrm{mol} / \mathrm{L})\end{array}$ \\
\hline Control & $0.65^{\mathrm{a}} \pm 0.10$ & $2.60 \pm 0.10$ & $11.7 \pm 0.20$ & $0.39 \pm 0.06$ & $136^{\mathrm{ab}} \pm 23.4$ & $335 \pm 49.1$ \\
\hline Oxidised oil & $0.33^{b} \pm 0.05$ & $2.38 \pm 0.23$ & $11.6 \pm 0.30$ & $0.60 \pm 0.05$ & $173^{\mathrm{a}} \pm 31.0$ & $394 \pm 60.6$ \\
\hline $\begin{array}{l}\text { Oxidised oil } \\
+ \text { vitamin E }\end{array}$ & $0.47^{\mathrm{ab}} \pm 0.09$ & $2.53 \pm 0.09$ & $11.5 \pm 0.33$ & $0.49 \pm 0.09$ & $89.2^{b} \pm 9.23$ & $380 \pm 62.9$ \\
\hline \multicolumn{3}{|c|}{ Source of variation } & \multicolumn{3}{|c|}{ Probabilities $(P$ value $)$} & \\
\hline Group & 0.035 & 0.635 & 0.883 & 0.194 & 0.041 & 0.771 \\
\hline
\end{tabular}

${ }^{*}$ LS - Mean \pm SEM.

a,b LS - Means within columns with no common superscript differ significantly $(P<0.05)$.

MDA - malondialdehyde; GSH-Px - glutathione peroxidise.

A large variation in GSH-Px activity appears to have been caused by individual variation in response to the oxidised oil treatment. Shaaban et al. (2003) also obtained significant differences in GSH-Px activity in different genotypes of chicken. GSH-Px removes hydrogen peroxide and lipid hydroperoxides from cells 
(Shaaban et al., 2003; Surai, 2003). Therefore, a higher GSH-Px activity in birds fed oxidised oil, can be explained by enzyme synthesis which may be an adaptive response to greater hydrogen peroxide production and to greater oxidative stress in the present study. Supporting this result, Davies (2000) and Surai (2003) reported that organs can adapt to oxidative stress by increasing their production of antioxidant and repair enzymes and restore the antioxidant/pro-oxidant balance. A similar response has been reported for rats, in which feeding oxidised oil resulted in increased antioxidant enzyme activities (Hayam et al., 1995; Juskiewicz et al., 2000). Furthermore, Iqbal et al. (2002) suggested that higher GSH-Px and SOD activities observed in the liver tissue of broilers with ascites, may be the response to a greater degree of oxidative stress. Supporting our findings, Maraschiello et al. (1999) observed that lipid and cholesterol oxidation were positively correlated with GSH-Px activity, suggesting that the GSH-Px activity can be used as an indicator of meat oxidative stability. However, some contradictory results were reported for antioxidant enzyme activity in relation to dietary oxidised oil. While Engberg et al. (1996) reported that the total GSH-Px activity in broilers was not influenced by oxidised oil, Keller et al. (2004) suggested that oxidised dietary oils reduced the antioxidant enzyme activities such as super oxide dismutase (SOD), catalase (CAT) and GSH-Px of erythrocytes in rats and guinea pigs.

In the present study the broilers were reared at a high ambient temperature, and the heat stress caused increases in MDA levels and antioxidant enzyme activities (GSH-Px, SOD and CAT), leading to oxidative stress (Altan et al., 2000; 2003). Eder et al. (2002) also indicated that feeding rats with oxidised fat reduced the activity of GSH-Px in either high or low selenium diets. In birds fed oxidised oil, supplementing the diet with $200 \mathrm{mg}$ vitamin E/kg depressed the GSH-Px activity in erythrocytes (Table 3). It seems possible, therefore, that the higher level of vitamin E might control the level of oxygenated radical scavenging systems such as GSH-Px and depress antioxidant enzyme activities by homeostatic compensation. The decrease in the GSH-Px activity found in the present study, agrees with that of Maraschiello et al. (1999) who reported a lower oxidant enzyme activity in broilers supplemented with $\alpha$ - tocopherol. In some stress conditions, the first stage of antioxidant defence in cells (antioxidant enzymes and metal binding proteins) is not able to prevent free radical formation. In this case, the second stage of defence consists of chain-breaking antioxidants. Uric acid, an end-product of purine metabolism, is a chain-breaking antioxidant and scavenger of single oxygen and radicals (Surai, 2003). In the present study, feeding oxidised oil and vitamin E supplementation did not alter uric acid levels in treatment groups, suggesting more mildly oxidative stress (Table 3).

Table 4 The effects of moderately-oxidised oil and vitamin E supplementation in the grower diet, on meat colour and $\mathrm{pH}$ values of breast meats (LS Mean $\pm \mathrm{SEM}$ )

\begin{tabular}{|c|c|c|c|c|}
\hline \multirow{2}{*}{ Treatment groups } & \multicolumn{3}{|c|}{ Colour parameters } & \multirow{2}{*}{$\mathrm{pH}$} \\
\hline & $\mathrm{L}^{*}$ & $a^{*}$ & $\mathrm{~b}^{*}$ & \\
\hline Control & $42.1^{\mathrm{b}} \pm 0.78$ & $-1.07 \pm 0.09$ & $6.37 \pm 0.34$ & $5.83 \pm 0.01$ \\
\hline Oxidised oil & $46.1^{\mathrm{a}} \pm 1.15$ & $-0.80 \pm 0.12$ & $6.15 \pm 0.30$ & $5.84 \pm 0.02$ \\
\hline Oxidised oil + vitamin E & $47.1^{\mathrm{a}} \pm 1.29$ & $-1.16 \pm 0.12$ & $5.49 \pm 0.32$ & $5.82 \pm 0.02$ \\
\hline Source of variation & \multicolumn{4}{|c|}{ Probabilities ( $P$ value $)$} \\
\hline Group & $0.0275^{*}$ & 0.0644 & 0.1419 & 0.8808 \\
\hline
\end{tabular}

There were no significant differences between the treatments in redness $\left(\mathrm{a}^{*}\right)$, yellowness $\left(\mathrm{b}^{*}\right)$ or $\mathrm{pH}$, whereas the $\mathrm{L}^{*}$ value was significantly lower in the control group compared to the oxidised oil and vitamin E supplemented groups (Table 4 ). As the $b^{*}$ value increases, poultry meat is characterized as yellow-brown whereas lower $b^{*}$ values cause poultry meat to go ivory-cream pink (Jensen et al., 1997). Lower L* and slightly higher $b^{*}$ values in the control group indicated darker coloured breast meat compared to the vitamin 
E supplemented group. Colour differences on CIE-Lab coordinates can be discerned by the most normal observers, and consumers can detect one CIE-Lab unit change in colour coordinates (Zhu \& Brewer, 1999). Although there were no statistically significant differences in the $b^{*}$ values of groups, colour development in the vitamin E supplemented group could be detected by the naked eye as light coloured breast meat, compared to other groups. Likewise, dietary vitamin E increases the stability of membrane-bound lipids and delays oxidation of red oxymyoglobin to brown metmyoglobin, thus improving the colour stability of the meat. These beneficial effects of vitamin E have been reported by Faustman et al. (1998) and Morrisey et al. (1998). However, Coetzee \& Hoffman (2001) were not able to obtain a beneficial effect of vitamin E on colour measurements in broiler meat. In turkey meat, Mercier et al. (1998) also reported that vitamin E supplementation delays lipid oxidation, but has no positive effect on colour stability.

\section{Conclusion}

We have hypothesized that detrimental effects of dietary oxidised oil are more pronounced in broilers reared at high ambient temperatures than at lower temperatures. Surprisingly, in spite of a high ambient temperature, feeding moderately oxidised oil did not cause drastic decreases in growth, feed consumption or feed efficiency of the broilers. Although the consumption of oxidised oil induces oxidative stress, there was only a slight increase in GSH-Px activity and MDA level. Supplementation of a diet with vitamin E (200 $\mathrm{mg} / \mathrm{kg}$ ) resulted in some alleviation of these adverse effects. Feeding oxidised oil did not cause a marked discolouration of breast meat, although vitamin $\mathrm{E}$ supplementation had a beneficial effect on colour measurements.

In conclusion, birds receiving adequate nutrients, particularly protein and vitamin $\mathrm{E}$, were able to metabolise the undesirable components in oxidised oil and respond to mild oxidative stress by reregulating antioxidant defences and other protective mechanisms that exist in the cell for maintaining homeostasis.

\section{Acknowledgements}

We wish to thank the Scientific Research Projects Committee of Ege University and Özlem Tarım Ürünleri A.Ş. for their contribution to this study (Project number: 2002-BİL-027).

\section{References}

Altan, O., Altan, A., Oguz, I., Pabuccuoglu, A. \& Konyalioglu, S., 2000. Effects of heat stress on growth, some blood variables and lipid oxidation in broilers exposed to high temperature at an early age. $\mathrm{Br}$. Poult. Sci. 41, 489-493.

Altan, O., Pabuccuoğlu, A., Altan, A., Konyalioğlu, S. \& Bayraktar, H., 2003. Effect of heat stress on oxidative stress, lipid peroxidation and some stress parameters in broilers. Br. Poult. Sci. 44, 545-550.

Asghar, A., Lin, C.F., Gray, J.I., Buckley, D.J., Booren, A.M., Crackel, R.L. \& Flegal, C.J., 1989. Influence of oxidised dietary oil and antioxidant supplementation on membrane-bound lipid stability in broiler meat. Br. Poult. Sci. 30, 815-823.

Barja, G., Cadenas, S., Rojas, C., Perez-Campa, R., Lopez-Torres, M., Prat, J. \& Pamplona, R., 1996. Effect of dietary vitamin $\mathrm{E}$ levels on fatty acid profiles and nonenzymatic lipid peroxidation in the guinea pig liver. Lipids 31, 963-970.

Cabel, M.C., Waldroup, P.W., Shermer, W.D. \& Calabotta, D.F., 1988. Effect of ethoxyquin feed preservative and peroxide level on broiler performance. Poult. Sci. 67, 1725-1730.

CIE, 1986. Colorimetry. $2^{\text {nd }}$ ed. Publication CIE No. 15.2. Vienna, Austria.

Coetzee, G.J.M. \& Hoffman, L.C., 2001. Effects of dietary vitamin E on the performance and quality of broiler meat during refrigerated and frozen storage. S. Afr. J. Anim. Sci. 31, 153-172.

Davies, K.J.A., 2000. Oxidative stress, antioxidant defences, and damage removal, repair, and replacement systems. Life 50, 279-289.

Dibner, J.J., Atwell, C.A., Kitchell, M.L., Shermer, W.D. \& Ivey, F.J., 1996. Feeding of oxidised fats to broilers and swine: effect on enterocyte turnover, hepatocyte proliferation and the gut associated lymphoid tissue. Anim. Feed Sci. Technol. 62, 1-13.

Eder, K., 1999a. The effect of an oxidised dietary oil on plasma cholesterol and thyroid hormone concentrations in miniature pigs fed on a hyperlipidaemic diet. J. Anim. Physiol. An. N. 82, 271-281.

Eder, K., 1999b. The effects of dietary oxidised oil on lipid metabolism in rats. Lipids 34, 717-725. 
Eder, K. \& Kirchgessner, M., 1998. The effect of dietary vitamin E supply and moderately oxidised oil on activities of hepatic lipogenic enzymes in rats. Lipids 33, 277-283.

Eder, K. \& Kirchgessner, M., 1999. The effect of a moderately thermoxidised dietary fat on the vitamin E status, the fatty acid composition of tissue lipids, and the susceptibility of low-density lipoproteins to lipid peroxidation in rats. Fett/Lipid 101, 178-184.

Eder, K., Skufca, P. \& Brandsch, C., 2002. Thermally oxidised dietary fats increase plasma thyroxin concentrations in rats irrespective of the vitamin E and selenium supply. J. Nutr. 132, 1275-1281.

Eder, K., Keller, U., Hirche, F. \& Brandsch, C., 2003. Thermally oxidised dietary fats increase the susceptibility of rat LDL to lipid peroxidation but not their uptake by macrophages. J. Nutr. 133, 2830-2837.

Engberg, R.M., Lauridsen, C., Jensen, S.K. \& Jakobsen, K., 1996. Inclusion of oxidised vegetable oil in broiler diets: It's influence on nutrient balance and on the antioxidative status of broilers. Poult. Sci. $75,1003-1011$.

Etches, R.J., John, J.M. \& Gibbins, A.M.V., 1995. Behavioural, physiological, neuroendocrine and molecular responses to heat stress. In: Poultry production in hot climates. Ed. Daghir, N.J., CAB International, Nosworthy Way, Wallingford, Oxfordshire, OX10 8DE UK.

Faustman, C., Chan, W.K.M., Schaefer, D.M. \& Haevens, A., 1998. Beef colour update: The role for vitamin E. J. Anim. Sci. 76, 1019-1026.

Fei, C.S., 1995. The detrimental effects of feeding oxidised fats to animals. ASA Tech. Bul., P021-1995.

Gous, R.M. \& Morris, T.R., 2005. Nutritional interventions in alleviating the effects of high temperatures in broiler production. Wrld's Poult. Sci. J. 61, 463-475.

Guo, Y., Tang, Q., Yuan, J. \& Jiang, Z., 2001. Effects of supplementation with vitamin E on the performance and the tissue peroxidation of broiler chicks and the stability of thigh meat against oxidative deterioration. Anim. Feed Sci. Technol. 89, 165-173.

Halliwell, B., Gutteridge, J.M.C. \& Cross, C.E., 1992. Free radicals, antioxidants and human disease: Where are we now? J. Lab. Clin. Med. 119, 589-620.

Hayam, I., Cogan, U. \& Mokady, S., 1995. Dietary oxidised oil and the activity of antioxidant enzymes and lipoprotein peroxidation in rats. Nutr. Res. 15, 1037-1044.

Hocgraf, E., Cogan, U. \& Mokady, S., 2000. Dietary oxidised linoleic acid enhances liver cholesterol biosynthesis and secretion in rats. J. Nutr. Biochem. 11, 176-180.

Iqbal, M., Cawthon, D., Beers, K., Wideman Jr., R.E. \& Bottje, W.G., 2002. Antioxidant enzyme activities and mitochondrial fatty acids in pulmonary hypertension syndrome (PHS) in broilers. Poult. Sci. 81, 252-260.

Jakobsen, C., 1999. Sensory impact of lipid oxidation in complex food system. Fett/Lipid 101, 484-492.

Jakobsen, K., Engberg, R.M. \& Hartfiel, W., 1993. The biological activity of natural source tocopherols in chickens fed fresh or oxidised fat rich in linoleic acid. Arc. Anim. Nutr. 44, 339-355.

Jankowski, J., Zdunczyk, Z., Koncicki, A., Juskiewicz, J. \& Faruga, A., 2000. The response of turkeys to diets containing oxidised fat of differing degree of oxidation. J. Anim. Feed Sci. 9, 363-370.

Jankowski, J., Zdunczyk, Z., Juskiewicz, J., Koncicki, A. \& Faruga, A., 2001. Einfluß einer lang-oder kurzfristigen anwendung von lipidperoxiden und von wärmestre $\beta$ auf die wachstumsleistung von puten. Arc. Gefl. 65, 1-4. (in German).

Jensen, C., Engberg, R., Jacobsen, K., Skibsted, L.H. \& Bertelsen, G., 1997. Influence of the oxidative quality of dietary oil on broiler meat storage stability. Meat Sci. 47, 211-222.

Juskiewicz, J., Dlugoszewska, M., Zdunczyk, Z., Krasnodebska-Depta, A., Krefft, B. \& Sadowska, J., 2000. The response of rats to long-term feeding with diets containing oxidised fat. 2. Biochemical indicator in the serum, liver, and bone mineralization. J. Anim. Feed. Sci. 9, 149-157.

Keller, U., Brandsch, C. \& Eder, K., 2004. The effect of dietary oxidised fats on the antioxidant status of erythrocytes and their susceptibility to haemolysis in rats and guinea pigs. J. Anim. Physiol. An. N. 88, $59-72$.

Kirunda, D.F.K., Scheideler, S.E. \& Mckee, S.R., 2001. The efficacy of vitamin E (DL- $\alpha$-tocopheryl acetate) supplementation in hen diets to alleviate egg quality deterioration associated with high temperature exposure. Poult. Sci. 80, 1378-1383. 
Lin, C.F., Asghar, A., Gray, J.I., Buckley, D.J., Booren, A.M., Crackel, R.L. \& Flegal, C.J., 1989. Effects of oxidised dietary oil and antioxidant supplementation on broiler growth and meat stability. Br. Poult. Sci. 30, 855-864.

Lin, H., Du, R. \& Zhang, Z.Y., 2000. Peroxide status in tissues of heat-stressed broilers. Asian-Aust. J. Anim. Sci. 13, 1347-1498.

Maraschiello, C., Sarraga, C. \& Regueiro, J.A.G., 1999. Glutathione peroxidase activity, t-bars, and alphatocopherol in meat from chickens fed different diets. J. Agr. Food Chem. 47, 867-872.

Mercier, Y., Gatellier, P., Viau, M., Remignon, H. \& Renerre, M., 1998. Effects of dietary fat and vitamin E on colour stability and on lipid and protein oxidation in turkey meat during storage. Meat Sci. 48, 301-318.

Morrissey, P.A., Sheehy, P.J.A., Galvin, K., Kerry, J.P. \& Buckley, D.J., 1998. Lipid stability in meat and meat products. Meat Sci. 49, 73-86.

Narasimhamurthy, K. \& Raina, P.L., 1999. Long term feeding effects of heated and fried oils on lipids and lipoproteins in rats. Mol. Cell. Biochem. 195, 143-153.

Naumann, C. \& Bassler, R., 1993. Die chemische Untersuchung von Futtermitteln, (Darmstadt, VDLUFAVerlag). (in German).

Puthpongsiriporn, U., Scheideler, S.E., Sell, J.L. \& Beck, M.M., 2001. Effects of vitamin E and C supplementation on performance, in vitro lymphocyte proliferation, and antioxidant status of laying hens during heat stress. Poult. Sci. 80, 1190-1200.

SAS, 1985. Statistical Analysis Systems user's guide (5th ed.). SAS Institute Inc., Raleigh, North Carolina, USA.

Satoh, K., 1978. Serum lipid peroxide in cerebrovascular disorders determined by a new colorimetric method. Clin. Chim. Acta 90, 37-43.

Shaaban, G., Mezes, M. \& Hidas, A., 2003. Phenotypic variation in glutathione peroxidase activity in different genotypes of different age groups of chicken and its correlation with some production traits. Arch. Geflugelkd. 67, 217-224.

Sheehy, P.J.A., Morrissey, P.A. \& Flynn, A., 1993. Influence of heated vegetable oils and $\alpha$ - tocopheryl acetate supplementation on $\alpha$ - tocopherol, fatty acids and lipid peroxidation in chicken muscle. $\mathrm{Br}$. Poult. Sci. 34, 367-381.

Sheehy, P.J.A., Morrissey, P.A. \& Flynn, A., 1994. Consumption of thermally-oxidised sunflower oil by chicks reduces $\alpha$-tocopherol status and increases susceptibility of tissues to lipid oxidation. Br. J. Nutr. 71, 53-65.

Surai, P.F., 2003. Natural antioxidants in avian nutrition and reproduction. Nottingham University Press.

Tabatabaei, S.R.F., 2008. The effects of oral vitamin induction and consequence of experimental diabetes mellitus in rats. Pakistan J. Biol. Sci. 11, 633-637.

TS, 1991. Turkish Standard Institute. Animal feeds determination of metabolisable energy (chemical method), Publ. No. 9610, 1-3 (in Turkish).

TS, 2006. Turkish Standard Institute. Animal and vegetable fats and oils-determination of peroxide value. TS EN ISO 3960, Ankara-Turkey (in Turkish).

Wang, S.Y., Bottje, W.G., Maynard, P., Dibner, J. \& Shermer, W., 1997. Effects of santoquin and oxidised fat on liver and intestinal glutathione in broilers. Poult. Sci. 76, 961-967.

Wideman, J., 1986. Antinutritional factors associated with dietary fats and oils. In: Recent Advances in Animal Nutrition. Eds Haresign, W. \& Cole, D.J.A., London, Butterworths. pp. 47-75.

Yagi, K., 1984. Assay for blood plasma or serum. Methods in Enzymology 105, 328-331.

Yu, B.P., 1994. Cellular defences against damage from react oxygen species. Phys. Rev. 74, 139-162.

Zdunczyk, Z., Juskiewicz, J., Dlugoszewska, M., Frejnagel, S. \& Koncicki, A., 2000. The response of rats to long term feeding with diets containing oxidised fat. 1 . Thermooxidative changes of fat, body weight gain, feed consumption and utilisation of diets. J. Anim. Feed. Sci. 9, 139-148.

Zdunczyk, Z., Jankowski, J. \& Koncicki, A., 2002. Growth performance and physiological state of turkeys fed diets with higher content of lipid oxidation products, selenium, vitamin E and vitamin A. Wrld's Poult. Sci. J. 58, 357-364.

Zhu, L.G. \& Brewer, M.S., 1999. Relationship between instrumental and sensory color evaluation in a raw, fresh beef and chicken model system. J. Muscle Foods 10, 131-146. 